\title{
REGULASI PARTAI POLITIK DALAM MEWUJUDKAN PENGUATAN PERAN DAN FUNGSI KELEMBAGAAN PARTAI POLITIK
}

\author{
(Regulatory Political Parties to Realize Role and Function of \\ Strengthening Institutional Political Parties)
}

\author{
Teguh Imansyah \\ Badan Pembinaan Hukum Nasional-Kementerian Hukum dan HAM RI \\ Jalan Mayjen Sutoyo Nomor 10 Jakarta Timur \\ E-mail: improved_kilo@yahoo.co.id
}

Naskah diterima: 9 Desember 2012; revisi: 12 Desember 2012; disetujui: 15 Desember 2012

\begin{abstract}
Abstrak
Partai politik adalah pilar dari sistem demokrasi, sepak-terjang partai politik merupakan variabel yang mempengaruhi kualitas demokrasi. Jika partai politik menjalankan peran dan fungsinya dengan baik, kualitas demokrasi akan menjadi baik. Begitu pula sebaliknya.Namun realitas yang berkembang saat ini menunjukan lemahnya kelembagaan partai yang ada saat ini. Keadaan tersebut terlihat dari menurunnya tingkat kepercayaanj terhadap partai dan maraknya kasus pelanggaran hukum yang terjadi pada para kader partai. Permasalahannya adalah bagaimana regulasi sistem kepartaian yang ada dalam membentuk kelembagaan partai untuk memenuhi fungsinya sebagai partai politik sesuai dengan undang-undang. Dengan menggunakan metode penelitian sosio yuridis dapat disimpulkan bahwa regulasi kepartaian yang ada belum berpengaruh signifikan dalam penguatan kelembagaan partai. Lemahnya kelembagaan partai yang ada saat ini lebih disebabkan oleh sistem internal partai yang belum modern.

Kata kunci: partai politik, demokrasi, kelembagaan
\end{abstract}

\section{Abstract}

Politic party is a pillar of the democratic system, the actions of the political parties are variables that affect the quality of democracy. If political parties fulfill their respective roles and functions properly, the quality of democracy will be good, and vice versa. But the reality shows currently developing the institutional weakness of the existing parties. The situation can be seen from the decline in the level of trust in the party and the rampant cases of law violations that occurred at the party cadres. The issue is how the existing regulations of the party system in the form of institutional party to fulfill its function as a political party in accordance with the law. Using sosio-juridic research methods can be concluded that the regulation of party that is not significant in the institutional strengthening of the party. The institutional weakness of the existing party is more due to the party's internal systems were not modern.

Keywords: political party, democracy, institutional 


\section{A. Pendahuluan}

Indonesia telah memilih sistem demokrasi sebagai cara untuk mengelola kehidupan bernegaranya. Oleh sebab itu, partai politik ditempatkan sebagai salah satu instrumen penting dalam perwujudan demokrasi bangsa. Tidak dapat dipungkiri, bahwa partai politik adalah pilar dari sistem demokrasi. Tanpa partai politik, maka demokrasi tidak dapat bekerja dan berjalan, atau dapat juga dikatakan bahwa berfungsi dan bekerjanya kehidupan negara yang demokratis, amat tergantung pada keberadaan partai politiknya. Dengan adanya partai politik, aspirasi dan keinginan masyarakat dapat disalurkan dan diperjuangkan. Dalam konteks itu, partai politik berkewajiban melaksanakan sejumlah fungsi, diantaranya adalah sebagai mediasi antara rakyat dan pemerintah, pencalonan kandidat, mengorganisasi pemerintahan, mendorong akuntabilitas publik, pendidikan politik dan pengatur konflik. ${ }^{1}$

Pasal 11 ayat (1) Undang-Undang Nomor 2 Tahun 2008 tentang Partai Politik menyebutkan bahwa fungsi dari partai politik di Indonesia adalah: pertama, sebagai sarana pendidikan politik bagi anggota dan masyarakat luas agar menjadi warga negara Indonesia yang sadar akan hak dan kewajibannya dalam kehidupan bermasyarakat, berbangsa, dan bernegara; kedua, sebagai sarana penciptaan iklim yang kondusif bagi persatuan dan kesatuan bangsa Indonesia untuk kesejahteraan masyarakat; ketiga, sebagai sarana penyerap, penghimpun, dan penyalur aspirasi politik masyarakat dalam merumuskan dan menetapkan kebijakan negara; keempat, sebagai sarana partisipasi politik warga negara Indonesia; dan kelima adalah sebagai sarana rekrutmen politik dalam proses pengisian jabatan politik melalui mekanisme demokrasi dengan memperhatikan kesetaraan dan keadilan gender.

Banyaknya fungsi yang diemban oleh partai politik mengartikan bahwa partai-partai politik yang saat ini telah berdiri memiliki kewajiban untuk dapat membangun kapasitas dirinya sehingga memiliki kapabilitas yang cukup untuk memenuhi apa yang telah diamanatkan oleh undang-undang. Namun demikian, realitas yang terkandung didalam kekhasan masyarakat Indonesia yang majemuk baik secara norma adat, kesukuan, agama, hingga tingkat pendidikan dan kemapanan sosialnya menjadi tantangan lain yang harus diakomodasi oleh setiap partai yang ada.

Namun disisi lain, realitas yang berkembang saat ini justru menunjukan kelembagaan partai-partai yang ada sedang berada pada titik terendah. Keadaan tersebut dapat terlihat dari kasus-kasus pelanggaran hukum yang saat ini marak terjadi diantara para kader partai, khususnya bagi mereka yang telah duduk di Dewan Perwakilan Rakyat (DPR) maupun sebagai pejabat negara lainnya. Laporan yang di publikasikan oleh Indonesia Corruption Watch (ICW) memaparkan bahwa terdapat 52 kader partai politik yang terjerat kasus korupsi pada tahun 2012, dengan rincian 25 orang dari kalangan mantan DPR/DPRD, 24 orang dari kalangan kepala daerah dan 2 orang pengurus partai serta 1 orang yang menjabat sebagai menteri aktif.

Beberapa partai politik yang tercatat dalam laporan ini masuk dan terkait kasus korupsi

Lili Romli, "Masalah Kelembagaan Partai Politik di Indonesia Pasca Orde Baru," Jurnal Penelitian Politik (Volume 5 No. 1, 2008): 21. 


\section{RECHTSVINDING}

melalui jalur politik, diantaranya Partai Golkar, Partai Demokrat, Partai Demokrasi Indonesia Perjuangan (PDIP), Partai Amanat Nasional (PAN), Partai Kebangkitan Bangsa (PKB), Parta Keadilan Sejahtera (PKS), Partai Gerakan Indonesia Raya (Gerindra), Partai Persatuan Pembangunan (PPP). Modus yang sering dilakukan oleh politisi ini adalah memanfaatkan kewenangan jabatannya. Dengan begitu mereka dapat memainkan anggaran. ${ }^{2}$

Hasil kajian yang dilakukan oleh Kemitraan menyebutkan bahwa kasus-kasus korupsi yang melibatkan politisi, baik yang berasal dari lingkungan legislatif maupun eksekutif, sesungguhnya bukan semata-mata karena motif pribadi. Faktor kebutuhan partai politik akan dana besar agar bisa memenangkan pemilu telah mendorong para politisi untuk berlaku koruptif. Secara umum para politisi di DPR mempunyai empat cara dalam mengumpulkan dana, yaitu pertama, membuat kebijakan yang menguntungkan pihak tertentu; kedua, menyusun rencana proyek dan anggarannya dalam APBN yang kelak akan dikerjakan oleh pihak tertentu; ketiga, menjadi calo tender proyek; dan keempat, meminta imbalan atas pemilihan jabatan publik atau pimpinan BUMN. $^{3}$

Empat modus yang dilakukan oleh para politisi DPR untuk meraup dana, membuktikan bahwa telah terjadi kartelisme dalam tubuh legislatif dan partai. Hanta Yuda menjelaskan bahwa meluasnya kasus korupsi dan semakin menurunnya produktivitas kinerja lembaga legislatif, sangat berkaitan dengan manajemen pengorganisasian yang tidak transparan, oligarkis, dan transaksional di dalam tubuh partai.

The Indonesia Institute menemukan adanya indikasi kegagalan partai politik dalam menjalankan fungsi perekrutan politik secara demokratis, transparan, dan berbasis meritokrasi. Pengisian kepengurusan di dalam partai seringkali dilakukan melalui cara-cara yang kental dengan kartelisme. Tidak hanya kartelisme yang telah menggerogoti kelembagaan partai politik di Indonesia, namun virus pragmatisme juga menggerogoti perilaku para elite partai, kader, dan konstituen partai, virus oligarkisme menjangkiti model kepemimpinan dan pengambilan keputusan di dalam partai, dan virus faksionalisme yang melemahkan kelekatan organisasi partai. Dengan kondisi kelembagaan partai yang sedemikian rupa, tidak dapat diharapkan terciptanya ikatan idiologis didalam tubuh partai. Karena itu pula, gejala lompat pagar para politisi sering terjadi.

Setiap kegagalan dalam kelembagaan partai dapat ditelusuri sumber dari elemen-elemen mana yang mengalami disfungsi. Misalnya saja,terjadinya penguatan pragmatisme adalah dampak dari gagalnya partai politik menjalankan sistem kaderisasi, ideologisasi dan fungsi pendidikan politik bagi kader dan pemilih. Seperti alur kausalitas yang tidak terputus pragmatisme yang hidup didalam tubuh partai akan memerosotkan militansi kader, pada kondisi rendahnya militansi kader dan menguatnya pragmatisme pemilih, kembali partai akan cenderung menggunakan cara instan menarik simpati pemilih dengan menggunakan kekuatan politik uang. ${ }^{4}$

ICW, "Laporan Catatan Akhir Tahun ICW Terkait Korupsi Politik 2012", www.lensaindonesia.com (diakses 10 Desember 2012).

3 Kemitraan, Anomali Keuangan Partai Politik Pengaturan Dan Praktek, (Jakarta: Kemitraan, 2011).

4 Hanta Yuda Ar, "Sindrom Partai Gagal", Kompas 27 Mei 2011. 
Kenyataan-kenyataan terkait buruknya kelembagaan partai politik seperti yang telah dipaparkan, tentuakanberpengaruh padatingkat kepercayaan masyarakat terhadap partai politik. Hasil survei nasional yang pernah dilakukan Centre for Strategic and International Studies (CSIS) di 33 provinsi Indonesia menunjukkan, bahwa masyarakat pemilik hak pilih secara umum kecewa terhadap semua partai politik dan cenderung bingung untuk mendukung partai mana. Menurut hasil survei, sebanyak $48,4 \%$ responden menyatakan bahwa mereka tidak memiliki pilihan dalam pemilu. ${ }^{5}$ Survei tersebut juga menunjukkan, adanya anggapan responden bahwa saat ini semua partai politik sama saja sehingga tidak ada altenatif pilihan partai yang menjanjikan, munculnya sikap antipartai seperti ini tidak hanya merugikan partai politik, tetapi juga demokrasi di Indonesia secara keseluruhan. ${ }^{6}$

Sebagai organisasi modern setiap partai politik dituntut untuk mampu membangun mekanisme internal yang juga modern. Menurut Samuel Hutington, pelembagaan partai politik adalah proses pemantapan sikap dan perilaku partai politik yang terpola atau sistemik sehingga terbentuk suatu budaya politik yang mendukung prinsip-prinsip dasar sistem demokrasi. Kondisi kepartaian seperti itu tidak akan pernah terwujud apabila tidak pernah dilakukan upaya serius untuk memperbaikinya. Menyikapi hal ini, setidaknya terdapat tiga jalur yang dapat digunakan untuk mendorong terjadinya perbaikan, yaitu jalur masyarakat, jalur institusional, dan jalur partai itu sendiri.

Tidak dapat dipungkiri, rasanya cukup sulit bila mengharapkan gerak perbaikan lembaga kepartaian dimulai oleh internal partai itu sendiri. Oleh karenanya selain jalur masyarakat yang mengevaluasi partai melalui momentum pemilu, mendorong perbaikan partai melalui jalur institusional masih dipandang paling efektif yaitu dengan pembentukan regulasi yang dapat mendorong dan memfasilitasi partai-partai kearah format yang sesuai dengan karakteristik sistem demokrasi yang sehat.

Dalam rangka meminimalisir terjadinya pelemahan kelembagaan partai politik, regulasi yang dikenakan terhadap partai tidak hanya menyangkut fungsi-fungsi yang harus dijalankan partai melalui Undang-undang Nomor 2 tahun 2008 tentang Kepartaian. Namun, Undang-undang Nomor 8 tahun 2012 tentang Pemilihan Umum Anggota Dewan Perwakilan Rakyat, Dewan perwakilan Daerah, dan Dewan Perwakilan Rakyat Daerah, juga memberikan pengaturan kepada partai untukmempersiapkan dirinya memenuhi kriteria yang ditetapkan agar dapat turut berkompetesi dalam Pemilu.

Pemberlakuan Undang-Undang Nomor 2 Tahun 2008tentang Partai Politik dilakukan dalam rangka mewujudkan peningkatan peran, fungsi, dan tanggung jawab Partai Politik untuk dapat merespon kemajemukan masyarakat dalam kehidupan demokrasi. Sebagai sarana partisipasi politik masyarakat dalam mewujudkan cita-cita 


\section{$\mathrm{R}_{\text {juknaL }}^{\text {juTSVINDING }}$}

nasional, dinamika kepartaian yang tercipta diharuskan mampu menjaga dan memelihara keutuhan negara dengan tetap mewujudkan kedaulatan rakyat dalam kehidupan bernegara. Undang-Undang ini mengakomodasi beberapa paradigma baru dalam rangka penguatan sistem dan kelembagaan partai politik, melalui usaha demokratisasi internal partai politik, transparansi dan akuntabilitas dalam pengelolaan keuangan, peningkatan kesetaraan gender dan kepemimpinan partai politik.

Beberapa pengaturan dalam undang-undang ini kemudian diubah melalui Undang-Undang Nomor 2 Tahun 2011 tentang Perubahan Atas Undang-Undang Nomor 2 Tahun 2008 tentang Partai Politik, dalam rangka penyempurnaan kelembagaan partai politik. Pengaturan baru tersebut diarahkan pada dua hal, pertama, membentuksikap dan perilaku partai politik yang terpola atau sistemik sehingga terbentuk budaya politik yang mendukung prinsip-prinsip dasar sistem demokrasi. Hal ini ditunjukan dengan sikap dan perilaku partai politik yang memiliki sistem seleksi dan rekrutmen keanggotaan yang memadai dengan menggunakan sistem pengkaderan dan kepemimpinan politik yang kuat; kedua, memaksimalkan fungsi partai politik baik fungsi partai politik terhadap negara maupun fungsi partai politik terhadap rakyat melalui pendidikan politik dan pengkaderan serta rekrutmen politik yang efektif untuk menghasilkan kader-kader calon pemimpin yang memiliki kemampuan di bidang politik.

Sedangkan penerapan Undang-Undang Nomor 8 Tahun 2012 tentang Pemilihan Umum, dimaksudkan agar proses demokratisasi tetap terpelihara melalui Pemilu yang lebih berkualitas, demokratis, dapat dilaksanakan dengan baik, terkelola dan terlembaga. Beberapa Pengaturan bagi partai politik untuk dapat menjadi peserta Pemilu dimaksudkan agar tercipta Pemilu dengan derajat kompetisi yang sehat, partisipatif, mempunyai tingkat keterwakilan yang lebih tinggi, serta memiliki mekanisme pertanggungjawaban yang jelas, serta menciptakan penyelenggaraan Pemilu yang lebih berkualitas dari waktu ke waktu. ${ }^{7}$

\section{B. Permasalahan}

1. Bagaimana kondisi kelembagaan partai politik saat ini dalam menjalankan fungsinya sebagai partai politik?

2. Sejauhmana regulasi sistem kepartaian kelembagaan partai dalam mewujudkan fungsinya sebagai partai politik?

3. Bagaimana arah politik hukum kedepan terhadap penguatan kelembagaan partai politik.

\section{Metode Penelitian}

Untuk menjawab permasalahan tersebut di atas, penulis menggunakan metode penelitian yuridis sosiologis, yaitu meneliti tentang pengaturan kelembagaan partai politik dalam peraturan perundang-undangan serta bagaimana kondisi kelembagaan partai politik yang terjadi. Kondisi kelembagaan partai politik didapatkan melalui data sekunder berupa buku-buku, jurnal dan media massa. Data sekunder berupa bahan hukum primer digunakan mengetahui sejauhmana regulasi mengatur tentang kelembagaan partai politik. Terhadap data-data tersebut akan dianalisa

Lihat Penjelasan Umum Undang-Undang Nomor 8 tahun 2012 tentang Pemilihan Umum Anggota Dewan Perwakilan Rakyat, Dewan perwakilan Daerah, dan Dewan Perwakilan rakyat Daerah. 
secara deskriptif kualitatif yang bertujuan untuk mendeskripsikan rumusan jawaban atas permasalahan yang dikemukan dalam penelitian ini.

\section{Pembahasan}

\section{Kelembagaan partai Politik di Indonesia Saat ini}

Pelembagaan partai politik merupakan proses pemantapan sikap dan perilaku partai politik yang terpola atau sistemik sehingga terbentuk suatu budaya politik yang mendukung prinsip-prinsip dasar sistem demokrasi. Dalam menelaah kelembagaan partai, umumnya variabel-variabel yang menjadi bahan analisa adalah mengenai: ${ }^{8}$

1. Idiologi partai sebagai landasan platform, pemahaman sikap idiologis dan politik serta komitmen atas tujuan politik yang dicitacitakan;

2. Demokrasi internal, yang dapat dilihat dalam implementasi peraturan dan prosedur, pengambilan keputusan, desentralisasi sumber daya dan pengawasan terhadap pelaksanaan kekuasaan, serta seleksi dan model kepemimpinan yang berjalan;

3. Sistem kaderisasi yang didalamnya juga menyangkut sistem rekrutmen dan keberadaan program kaderisasi yang jelas;

4. Kohesivitas internal, yang terkait dengan kemampuan atas penyeleseian konflik internal;

5. Hubungan dengan konstituen; dan

6. Otonomi keuangan, dimana menyangkut kontinuitas dan pengelolaan sumber dana.

\section{a. Kelembagaan Partai dalam Anggaran dasar}

Bila meninjau dokumen anggaran dasar yang dimiliki oleh beberapa partai, dapat dilihat bahwa pasal-pasal yang ada didalamnya telah mengakomodasi kebutuhan-kebutuhan seperti nilai-nilai demokrasi internal, platform, pemeliharaan kohesivitas internal, dan lainlain.

Dalam anggaran dasarnya, Partai Demokrat menetapkan bahwa idiologi yang dianutnya adalah Nasionalis-Religius, dimana diimplementasikan dalam bentuk kerja keras untuk kepentingan rakyat dengan landasan moral dan agama serta memperhatikan aspek nasionalisme, humanisme dan pluralisme, dalam rangka mencapai tujuan perdamaian, demokrasi dan kesejahteraan rakyat. Sistem kaderisasi dan rekrutmen pada partai Demokrat bersifat terbuka untuk semua warga negara, tanpa membedakan suku bangsa, ras, profesi, jenis kelamin, agama dan kepercayaan. ${ }^{9}$

Bila dilihat dari struktur dan kewenangan yang disusun di dalam anggaran dasar, dapat dlihat bahwa Majelis Tinggi Partai merupakan pemilik kekuasaan tertinggi dalam partai struktur organisasi partai. Ketua Majelis Tinggi secara ex-officio dijabat oleh ketua dewan pembina sedangkan wakil ketua Majelis Tinggi Partai secara ex-officio dijabat oleh Ketua Umum Dewan Pimpinan Pusat. Majelis Tinggi dalam partai Demokrat beranggotakan 9 orang yang terdiri atas Ketua, Wakil Ketua, Sekretaris, dan 6 orang anggota, dimana anggota Majelis Tinggi Partai diangkat dan ditetapkan oleh Ketua Majelis Tinggi Partai. Banyak kewenangan penting yang

Ibid., hlm. 188.

Pasal 6 Anggaran Dasar Partai Demokrat. 


\section{$\mathrm{R}_{\text {juknaL }}^{\text {juTSVINDING }}$

dimiliki oleh Majelis Tinggi khususnya terkait keputusan-keputusan strategis tentang: a. calon Presiden dan Wakil Presiden; b. calon Pimpinan DPR RI, Pimpinan dan Alat Kelengkapan Fraksi Partai Demokrat di DPR/ MPR RI; c. calon partaipartai anggota koalisi; d. calon-calon anggota legislatif pusat; e. calon-calon gubernur dan wakil gubernur dalam Pemilihan kepala daerah; dan f. rancangan Anggaran Dasar dan Anggaran Rumah Tangga serta program kerja 5 (lima) tahun untuk disahkan dalam Kongres. Segala keputusan terkait hal tersebut kemudian akan disampaikan kepada Dewan Pimpinan Pusat untuk dilaksanakan. Pengisian jabatan ketua umum dan ketua dewan pembina sendiri dipilih dan ditetapkan dalam kongres melalui proses musyawarah.

Dalam rangka pemeliharaan kosehivitas internal, partai demokrat memberikan kewenangan kepada Dewan Kehormatan untuk memeriksa, memutuskan dan atau menjatuhkan sanksi atas pelanggaran etika, moral dan pelanggaran terhadap ketentuan organisasi yang dilakukan oleh pengurus partai dan kader partai yang ditugaskan dilembaga eksekutif dan legislatif ditingkat pusat dan propinsi, atas laporan dari Komisi Pengawas atau pihak lain. Ketua Dewan Kehormatan dijabat secara exofficio oleh Ketua Dewan Pembina, sedangkan Wakil Ketua Dewan Kehormatan dijabat secara ex-officio oleh Ketua Umum Dewan Pimpinan Pusat.

Begitu juga dengan partai lainnya, seperti Partai Persatuan Pembangunan (PPP), di dalam AD/ART-nya PPP menegaskan bahwa kedaulatan partaiberada ditangan anggota dan dilaksanakan sepenuhnya oleh muktamar. Di dalam muktamar ini ditentukan setiap kepengurusan harian Dewan Pimpinan Pusat dan majelismajelis paratai, seperti kepengurusan Majelis Syariah, pimpinan Majelis Pertimbangan Dewan Pimpinan Pusat, Pimpinan Majelis Pakar Dewan Pimpinan Pusat, sedangkan kepengurusan departemen dan lembaga-lembaga yang ada didalam partai dipilih oleh pengurus harian dewan pimpinan pusat. Tujuan pokok partai yaitu mewujudkan masyarakat madani, yang adil dan makmur, sejahtera lahir bathin, dan demokratis dalam wadah Negara Kesatuan Republik Indonesia yang berdasarkan Pancasila dibawah Ridha Allah Subhanahu Wata'ala. ${ }^{10}$

PPP menetapkan asas partainya adalah Islam. Meskipun demikian partai ini masih mengusung inklusifitas, persyaratan yang tercantum dalam Anggaran Rumah Tangga (ART) PPP tidak meyebutkan "beragama Islam" sebagai salah satu persyaratan. Didalam dokumen ART hanya tertulis bahwa persyaratan untuk menjadi anggota Partai Persatuan Pembangunan adalah; a) telah berumur 17 (tujuh belas) tahun atau sudsah/pernah menikah; b) menyetujui dan melaksanakan Anggaran Dasar dan Anggaran Rumah Tangga serta Program Perjuanagn Partai Persatuan Pembangunan; c) sanggup aktif mengikuti kegiatan-kegiatan Partai Persatuan Pembangunan.

Satu lagi partai yang berlandaskan Islam adalah Partai Keadilan Sejahtera, Platform Kebijakan Pembangunan PK Sejahtera didasarkan pada paradigma dan konsensus nasional. Pancasila sebagai Dasar Negara secara konsepsional mengandung nilai-nilai Ketuhanan Yang Maha Esa (tauhid), Demokrasi (syura), Hak Asasi Manusia (maqashid syari'ah), Pluralitas

10 Lihat dokumen Anggaran Dasar Partai Persatuan Pembangunan (PPP), hasil Muktamar VI tahun 2007. 
Persatuan dan Kesatuan, dalam semangat kekeluargaan dan kebersamaan yang harmonis serta untuk mewujudkan keadilan sosial bagi seluruh rakyat Indonesia. Nilai-nilai tersebut menjadi landasan idiil kehidupan bersama; serta nilai-nilai dalam UUD digunakan sebagai landasan konstitusional Platform Kebijakan Pembangunan ini. Tujuan didirikannya PK Sejahtera, sebagaimana tertuang dalam Anggaran Dasar PK Sejahtera pasal 5, yaitu: ${ }^{11}$

1. Terwujudnya cita-cita nasional bangsa Indonesia sebagaimana dimaksud dalam Pembukaan Undang-Undang Dasar Negara Republik Indonesia tahun 1945; dan

2. Terwujudnya masyarakat madani yang adil dan sejahtera yang diridlai Allah subhanahu wa ta'ala, dalam Negara Kesatuan Republik Indonesia.

Dapat dikatakan hampir tidak ada perbedaan yang tegas antara paltform dari masing-masing partai. Cita-cita yang di cantumkan dalam anggaran dasar memiliki kemiripan satu sama lain, antara PK Sejahtera dengan PPP samasama bertujuan menciptakan masyarakat madani, yang adil dan makmur, sejahtera, dan demokratis dalam wadah Negara Kesatuan Republik Indonesia. Demikian juga dengan partai Demokrat, hanya sedikit perbedaan dengan penulisan yang lebih singkat yaitu menciptakan tujuan perdamaian, demokrasi dan kesejahteraan rakyat.

Ketidakjelasan platform dan batas perbedaan idiologi antar parpol yang tidak tegas, beresiko menjadikan kader parpol dapat meloncat-loncat dengan leluasa dari satu partai ke partai lain. Dampak lebih buruk yang bisa terjadi adalah terbangunnya sistem rekrutmen parpol yang lebih inklusif dan pragmatis dengan orientasi dominan untuk penambahan suara (vote seeking). Sehingga yang terjadi adalah, siapapun yang punya basis massa dan finansial yang kuat untuk memenangkan pemilihan akan ditawari oleh partai untuk menjadi kadernya. Dalam sistem yang sedemikian rupa proses kaderisasi dan keberadaan idiologi sudah tidak lagi penting, karena dengan pargmatisme tersebut partai telah dapat memperkuat hasil pengumpulan suaranya dalam pemilu.

Agak berbeda dengan apa yang termuat dalam Anggaran Dasar dan Anggaraan Rumah Tangganya (AD/ART), Partai Amanat Nasional (PAN), justru tidak mencantumkan idiologi apa yang dianut oleh partai ini. Pada pasal 4, AD/ART-nya PAN hanya menyebutkan bahwa PAN berdasarkan Pancasila dan berasaskan akhlak politik dengan berlandaskan agama yang membawa rahmat bagi sekalian alam. Pebedaan sedikit terlihat dari isi tujuan pokok partai PAN, yaitu mewujudkan Indonesia Baru yang menjunjung tinggi dan menegakan nilainilai iman dan takwa. Kalimat "mewujudkan Indonesia baru" menunjukan bahwa partai ini mengandaikan adanya format lama dari sistem bernegara selama ini yang harus ditinggalkan, dan digantikan dengan format yang sama sekali baru. Namun kemudian, format baru yang dibayangkan kembali sama yaitu terciptanya kedaulatan rakyat, keadilan sosial, kemakmuran dan kesejahteraan dalam wadah Negara Republik Indonesia.

Yang menarik dari keorganisasian PAN adalah keberadaan Mahkamah Penyelesaian

11 Membangun Masyarakat Madani; Falsafah Dasar Perjuangan dan Platform Kebijakan Pembangunan PK Sejahtera, di susun oleh Majelis Pertimbangan Pusat Partai Keadilan Sejahtera, 2008. 


\section{$\mathrm{R}_{\text {juknaL }}^{\text {juTSVINDING }}$

Sengketa (MPS), yang berada di tingkat Dewan Pimpinan Pusat dan berwenang menyelesaikan sengketa yang terjadi dalam tubuh partai. Lebih dari itu, dalam kelembagaan partai juga dikenal pendekatan pemberian penghargaan bagi kader, anggota, dan simpatisan yang berjasa terhadap partai, Sanksi bagi anggota maupun pengurus partai yang melakukan tindak pidana kejahatan dan/atau melakukan pelanggaran terhadap undang-undang, Anggaran Dasar, Anggaran Rumah Tangga dan peraturan-peraturan partai, dan rehabilitasi yaitu pemulihan nama baik, harkat, martabat, dan hak anggota dan atau pengurus.

Perbedaan yang cukup mencolok dapat ditemukan pada platform Partai Demokrasi Indonesia Perjuangan (PDI Perjuangan), Partai ini berasaskan Pancasila 1 Juni 1945, dan peran partai difokuskan kepada usaha-usaha untuk mencapai cita-cita bersama di dalam Pancasila tersebut.Untukitu, PDI Perjuangan berketetapan menjadi alat perjuangan dan pengorganisasian rakyat. Sebagai alat rakyat, PDI Perjuangan bertugas untuk: pertama, mewujudkan amanat penderitaaan rakyat sebagaimana termaktub dalam cita-cita Negara Proklamasi 17 Agustus 1945; kedua, menjaga dan melaksanakan Pancasila 1 Juni 1945 sebagai dasar dan arah berbangsa dan bernegara; sebagai sumber inspirasi dan harapan bagi rakyat; sebagai norma pengatur tingkah laku kebijakan, kelembagaan dan anggota partai; dan sebagai cermin dari keseluruhan jati diri partai; dan ketiga, mengantarkan Indonesia untuk berdaulat dalam bidang politik, berdikari dalam bidang ekonomi, dan berkepribadian dalam kebudayaan sebagai syarat-syarat minimum bagi perwujudan citacita bersama bangsa di atas. ${ }^{12}$

Namun demkian, dalam realitasnya tidak ada jaminan bagaimana kelembagaan internal dari setiap partai telah sesuai dengan apa yang tertulis dalam AD/ART. Sebagai sebuah perangkat organisasi, apa yang ada dalam anggaran dasar tentu akan dipenuhi namun sebagai suatu kelembagaan yang utuh, hanya dapat diukur melalui apa yang tampak dari perilaku organisasi partai secara aktual.

Pada dasarnya terdapat banyak faktor yang bisa mempengaruhi proses pelembagaan partai, bergantung dari sisi mana kita melihatnya. Ada yang mengatakan bahwa pelembagaan sebuah partai sangat berkaitan dengan usia partai tersebut. di sisi lain, dari lamanya usia partai dapat dilihat bagaimana konsistensi pelaksanaan fungsi partai dan sistem kepartaian yang teraktualisasi, sehingga semakin lama eksistensi suatu partai maka semakin terlembaga unitunit organisasi yang ada didalam struktur organisasi partai tersebut. Selain itu, terdapat juga pandangan yang mengatakan bahwa sistem kepartaian yang digunakan juga akan mempengaruhi pola pelembagaan partai, dimana semakin tinggi tingkat kompetisi yang dibangun dalam sebuah partai, semakin tinggi tingkat kompetisi yang dibangun dalam sebuah sistem, semakin kuat dorongan didalam partai untuk mencari terobosan dan melakukan tindakan kreaatif. ${ }^{13}$

Diluar dari faktor usia dan sistem kepartaian yangmempengaruhi proses pelembagaan partai, masih banyak faktor lain yang sesungguhnya lebih kuat menentukan karakter kelembagaan.

12 "Visi dan misi PDI-Perjuangan", www.pdiperjuangan.or.id (diakses 12 November 2012).

13 Edison Muchlis M, Perbandingan Pelembagaan Lima Partai Politik, dalam Sri Nuryanti (ed.) Pelembagaan Partai Politik di Indonesia Pasca Orde Baru, (Jakarta: LIPI, Pusat Penelitia Politik, 2007), hlm. 187. 
Robert Michels $^{14}$ menyatakan bahwa partai politik, sebagai sebuah entitas politik, sebagai sebuah mekanisme, tidak secara otomatis mengindetifikasi dirinya dengan kepentingan para anggotanya juga kelas sosial yang mereka wakili. Partai sengaja dibentuk sebagai alat untuk mengamankan tujuan. Juga menjadi bagian dari tujuan itu sendiri, memiliki tujuan dan kepentingan di dalam dirinya sendiri. Dalam sebuah partai, kepentingan massa pemilih yang telah membentuk partai kerap kali terlupakan oleh sebab terhalangi oleh kepentingan birokrasi yang dijalankan pemimpin-pemimpinnya.

\section{b. Kelembagaan Partai Aktual}

Dari hasil penelitian yang dilakukan oleh LIPI terhadap lima partai pemenang pemilu 2004, didapatkan beberapa poin permasalahan kelembagaan yang dihadapi oleh partaipartai yang ada saat ini. ${ }^{15}$ Dari sisi idiologi dan identitas partai, terdapat kesamaan dalam identitas masing-masing dan hanya sedikit ditemukan perbedaan, contohnya antara PPP, PKS dan PAN. Perbedaannya peletakan asas Pancasila, nasionalisme, pluralisme dan terbuka pada PAN, yang karenanya partai ini tidak ingin disebut partai islam. Sedangkan PDIP dan Partai Demokrat pada dasarnya menganut idiologi yang sama yaitu nasionalisme. Namun demikian, semangat nasionalisme pada partai Demokrat diinterpretasikan sebagai tidak membedakan ras, suku, bangsa, jenis kelamin, provesi, agama dan kepercayaan kepada tuhan. Sedangkan dasar nasionalisme yang dianut oleh PDIP yang diambildarikonsepsiMarhaenisme, berdasarkan idiologi Marhaenisme-Nassionalisme inilah kemudian PDIP mengambil jati diri sebagai kerakyatan.

Dalam hal demokrasi internal, kebanyakan dari partai yang ada masih mengandalkan peran figur, ketokohan atau yang sifatnya terpusat dalam peengambilan keputusan. Pola seperti ini membuat keputusan tertinggi tergantung pada keputusan yang dikeluarkan oleh pemimpin pusat partai, hanya dalam bentuk mekanisme pengambilan keputusan yang terlihat berbeda. Sangat kuatnya ketergantungan terhadap figur pemimpin partai politik dalam pengembangan eksistensi partai melalui pembangunan jaringan, sistem, komunikasi politik (internal maupun eksternal) hingga soal pendanaan partai, dapat dilihat misalkan dalam kelembagaan yang berjalan pada partai PDIP dengan kepemimpinan Megawati Soekarno Putri. Kondisi ini juga terjadi pada partai Demokrat dibawah kepemimpinan SBY dan PAN pada masa kepemimpinan Amien Rais.

Ketergantungan partai terhadap figur tidak hanya menyangkut pengembangan eksistensi partai. Dalam AD/ART semua parpol di Indonesia, termuat pasal yang menyatakan kedaulatan parpol berada di tangan para anggota. Namun aktualisasinya, hampir semua parpol di Indonesia masih dikelola secara sentralistik, oligarkhi, dan personalistik. Proses pengambilan keputusan dalam parpol, baik dalam penentuan kepengurusan serta nama calon anggota DPR, DPRD, presiden dan wakil presiden, dan kepala daerah dan wakil kepala daerah, maupun dalam penentuan kebijakan parpol, lebih banyak didominasi oleh pengurus pusat dan pengurus daerah daripada oleh Rapat Umum Anggota

14 Robert Michels, The Iron Law of Oligarchy, dalam Bernard E. Brown dan Roy C. Macridis, Comparative Politics: Notes and Readings, 8th Edition, (California: Wadsworth Publishing Company, 1996), hlm. 244-9.

15 Edison Muchlis M, Op.Cit., hlm. 195. 
(RUA). Pengurus parpol di tingkat lokal memang dapat memberikan usulan, tetapi keputusan akhir tetap berada pada pengurus pusat. Rapat Umum Anggota dengan sebutan yang berbeda antar parpol, seperti musyawarah, kongres, atau muktamar hanya dihadiri oleh pengurus parpol dari berbagai tingkatan, tidak diikuti oleh anggota secara umum. Pengurus parpol hanya memerlukan para anggota pada pemilu saja. Maka tidak mengherankan apabila hampir semua parpol tidak melaksanakan kewajiban yang ditentukan dalam undang-undang tentang Partai Politik, yaitu memelihara daftar anggota. ${ }^{16}$

Dalam hal pendekatan terhadap konstituen, cara yang digunakan oleh banyak partai politik adalah dengan menggunakan berbagai identitas, atribut, simbol-simbol, dan jargon yang menjadi ciri khas idiologis partai. Terdapat dua pola hubungan partai dengan konstituen yang selama ini umum dilakukan, yaitu hubungan secara langsung dan tidak langsung. Contoh hubungan langsung dengan konstituen misalnya dengan memberikan bantuan langsung kepada masyarakat yang terkena bencana alam. Sedangkan pola hubungan tidak langsung dilakukan melalui ormas-ormas yang menjadi sayap partai.

Yang terakhir, adalah terkait pendanaan partai. Urusan pendanaan partai adalah masalah yang paling krusial dalam masalah pelembagaan partai, karena urusan keuangan partai politik dapat mempengaruhi elemen kelembagaan lain, seperti pola kepemimpinan dan kekuasaan, rekrutmen kader potensial, penentuan kader partai yang dimajukan dalam suksesi Pemilu.
Ketika partai politik menjadi mesin pemilu, maka partai politik membutuhkan sumber daya yang besar agar mesin itu bisa berfungsi secara maksimal dalam mendulang suara pemilih. Disisi lain memudarnya ideologi telah melemahkan ikatan partai politik dengan anggotanya yang kemudian berdampak pada rapuhnya jaringan organisasi. Hal ini tentu saja berdampak pada turunnya kemampuan organisasi partai politik dalam memobilisasi pendukung. Akibatnya partai politik harus mencari cara lain agar eksistensi partai politk tetap terjaga baik dalam masyarakat, dan kemampuan meraih suara dalam pemilu tetap tinggi dalam pemilu.

Pada awalnya dana politik, baik dana operasional partai politik maupun dana kampanye, didapatkan dari iuran anggota partai politik. Namun seiring dengan meredupnya ikatan idiologis partai, kondisi iuran anggota tidak bisa diharapkan lagi, maka untuk mendapatkan dana besar, partai politik mau tidak mau berpaling kepada para penyumbang, baik penyumbang perseorangan, kelompok maupun lembaga, khususnya badan usaha. Di sinilah partai politik menghadapi dilema besar: di satu pihak, untuk mempertahankan pengaruh dan merebut suara rakyat, partai politik membutuhkan dana besar; di lain pihak, besarnya dana sumbangan membuat partai politik tergantung kepada para penyumbang, sehingga partai politik bisa terjebak kepada kepentingan para penyumbang dan melupakan misi memperjuangkan kepentingan rakyat. ${ }^{17}$

Seperti yang telah diungkapkan, bahwa para politisi di DPR mempunyai empat cara mengumpulkan dana bagi partai, yaitu dengan

\footnotetext{
16 Ramlan Surbakti dan Didik Supriyanto, Menjaga Kedaulatan Pemilih, Buku Seri Demokrasi Elektoral, (Jakarta: Kemitraan, September 2011), hlm. 12.

17 Kemitraan, bagi Pembaruan Tata Pemerintahan, Anomali Keuangan Partai Politik; Pengaturan Dan Praktek, (Jakarta: Kemitraan, November 2011), hlm. 3.
} 
membuat kebijakan yang menguntungkan pihak tertentu, menyusun rencana proyek dalam APBN yang kelak akan dikerjakan oleh pihak tertentu, menjadi calo tender proyek, dan meminta imbalan atas pemilihan jabatan publik atau pimpinan BUMN. Namun yang lebih menyedihkan, modus ilegal tersebut juga terjadi di DPRD provinsi dan kabupaten/ kota. Fragmentasi politik yang tinggi di DPRD provinsi dan DPRD kabuapten/kota merupakan tantangan tersendiri bagi gubernur dan bupati/ walikota dalam mengambil keputusan. Namun dengan politik transaksional, di mana gubernur dan bupati/walikota membagi-bagi dana proyek dan dana sosial APBD di kalangan anggota DPRD provinsi dan DPRD kabupaten/kota, roda pemerintahan tetap bisa berjalan, meskipun kebijakan yang diambil tidak pro rakyat. Inilah yang melatari banyaknya kepala daerah dan anggota DPRD terbelit kasus penggelapan dana APBD. ${ }^{18}$ Kondisi tersebut dapat terlihat dalam skandal-skandal korupsi yang terjadi pada para pejabat negara, dimana dirinya juga merupakan tokoh dari sebuah partai politik.

Sepanjang tahun 2012, media televisi dan media cetak memberikan suguhan berita tentang terungkapnya kasus-kasus korupsi. Sekurang-kurangnya 16 anggota DPR/DPRD telah tersangkut kasus korupsi, Kita dibuat semakin miris dengan pernyataan Menteri Dalam Negeri, Gamawan Fauszi, sebagaimana diberitakan berbagai media, menyatakan bahwa sepanjang tahun 2004-2012 sejumlah 173 Kepala Daerah terlibat kasus Korupsi. Jumlah tersebut berarti sepertiga dari jumlah seluruh daerah di Indonesia yang berjumlah 530 kabupaten/kota. ${ }^{19}$

Seperti yang telah diketahui, secara politik kabinet yang tersusun dalam pemerintahan di Indonesia, merupakan hasil dari akomodasi partai pemenang kursi presiden terhadap partaipartai lain pemilik kursi di DPR, dengan tujuan agar pemerintahan yang terbangun menjadi pemerintahan bersama yang stabil dan kokoh. Namun fenomena yang sering kali muncul dalam kehidupan politik di Indonesia, adalah kaburnya batasan profesionalisme seseorang antara dirinya sebagai pejabat pemerintahan ataukah sebagai kader atau pejabat tinggi suatu partai. Batas identitas ini semakin tidak jelas, karena seringkali penggunaan kewenangan atau kekeusaan sebagai pemerintah bercampur aduk dengan kepentingan, kewenangan dan kekuasaan yang dimilikinya sebagai kader partai politik.

\section{Regulasi Kepartaian, Antara Harapan dan Hambatan}

Sejak memasuki Era Reformasi pada tahun 1998, Indonesia telah menyelenggarakan secara periodik tiga kali pemilihan umum (Pemilu), yaitu Pemilu 1999, Pemilu 2004, dan Pemilu 2009. Pemilu 2014 akan menjadi Pemilu ke empat dalam Era Reformasi di Indonesia. Dalam perspektif demokrasi elektoral, Indonesia telah mampu melewati apa yang dalam studi demokrasi disebut the two-turnover test. Istilah ini merujuk pada kemampuan negara melewati fase transisi demokrasi menuju fase konsolidasi demokrasi berdasarkan keberhasilan menyelenggarakan dua kali Pemilu sejak

18 Ibid.

19 Koalisi Perempuan Indonesia, Refleksi 2012 \& Catatan Awal Tahun 2013, Kegaduhan Politik \& Maraknya Korupsi Di Tengah Kemiskinan Akut \& Kekerasan (Jakarta: Koalisi Perempuan Indonesia, 2013). 


\section{$\mathrm{R}_{\text {juknaL }}^{\text {juTSVINDING }}$}

Media Pembinaan Hukum Nasional

Volume 1 Nomor 3, Desember 2012

berakhirnya era kekuasaan otoriter. ${ }^{20}$ Pemilu yang ke empat nanti merupakan momentum bagi Indonesia memantapkan konsolidasi demokrasi.

Keberhasilan menyelenggarakan Pemilu tentu tidak dapat seketika disimpulkan Indonesia telah berhasilmewujudkan demokrasi substantif, meskipun demokrasi elektoral adalah prasyarat dan bagian esensial bagi demokrasi substantif. Demokrasi elektoral (demokrasi minimalis) dan demokrasi substantif (demokrasi maksimalis) mengandung makna dan memiliki ukuran berbeda. Jika realisasi demokrasi elektoral diukur hanya sebatas Pemilu yang bebas, kompetitif, dan demokratis, ${ }^{21}$ maka realisasi demokrasi substantif mensyaratkan lebih daripada sekadar penyelenggaraan Pemilu. ${ }^{22}$ Pemilu adalah sebuah mekanisme politik untuk mengartikulasikan aspirasi dan kepentingan warga negara. Setidaknya ada empat fungsi pemilu antara lain: Legitimasi Politik, terciptanya perwakilan politik, sirkulasi elite politik dan pendidikan politik. Melalui pemilu, legitimasi pemerintah/penguasa dikukuhkan karena ia adalah hasil pilihan warga negara yang memiliki kedaulatan. ${ }^{23}$

Sebagai suatu bentuk sistem demokrasi modern, sistem perwakilan tidak dapat berjalan baik tanpa kehadiran partai politik yang salah satu fungsinya sebagai intermediator antara elite politik dan konstituen. Literatur studi demokrasi umumnya menyebut adanya partai politik yang bebas, otonom, dan kompetitif merupakan conditio sine quo non bagi praktik demokrasi. ${ }^{24}$ Dalam posisi ini peran dan fungsi partai politik ikut menentukan kualitas praktik demokrasi perwakilan. Dalam pengertian ini, demokrasi perwakilan tidak hanya mensyaratkan kehadiran partai politik, tetapi juga menuntut partai politik memberi kontribusi positif dan konstruktif terwujudnya praktik demokrasi perwakilan berkualitas. Artinya, sepak-terjang partai politik merupakan variabel yang mempengaruhi kualitas demokrasi. Jika partai politik menjalankan peran dan fungsinya dengan baik, kualitas demokrasi akan menjadi baik. Begitu pula sebaliknya. ${ }^{25}$

20 Samuel P. Huntington, The Third Wave Democratization in the Late Twentieth Century, (Oklahoma: University of Oklahoma Press, Norman, 1991), hlm. 26-27.

21 Dalam literatur demokrasi, demokrasi elektoral disebut beraliran Schumpeterian karena berakar pada pendapat Joseph A. Schumpeter tentang "metode demokratis" mencapai keputusan politik. Dalam buku klasiknya berjudul Capitalism, Socialism and Democracy, Schumpeter berpendapat bahwa: "The democratic method is that institutional arrangement for arriving at political decisions in which individual acquire the power to decide by means of a competitive struggle for the people's vote." Lihat, Joseph A. Schumpeter, Capitalism, Socialism and Democracy, (London: Unwin Paperbacks, 1987), hlm. 269.

22 Menurut laporan penilaian praktik demokrasi di dunia yang dirilis oleh Freedom House, lembaga independen terkemuka dari Amerika Serikat yang melakukan riset dan advokasi demokrasi, berjudul Countries at the Crossroads 2012, kualitas demokrasi Indonesia menurun dan masuk dalam kelompok negara di persimpangan jalan. Penilaian ini didasarkan atas beberapa indikator, yaitu perlindungan terhadap kaum minoritas, jaminan keamanan bagi jurnalis melaksanakan tugasnya, dominasi kepemilikan media oleh segelintir elite, dan keseriusan pemberantasan korupsi. Indonesia mendapat nilai rendah terkait dengan indikator tersebut. (Lihat Kompas, "Skor Indonesia Kembali Memburuk", 19 September 2012, hlm. 1).

23 Muhammad AS Hikam, Politik Kewarganegaraan, Landasan Redemokratisasi di Indonesia (Jakarta: PT. Gelora Aksara Perdana, 1999), hlm. 16.

24 Afan Gaffar, Politik Indonesia Menuju Transisi Menuju Demokrasi, (Yogyakarta: Pustaka Pelajar, 1999), hlm. 8-9.

25 Munafrizal Manan, "Partai Politik dan Demokrasi Indonesia Menyongsong Pemilihan Umum 2014", Jurnal Legislasi Indonesia (Vol. 9 No. 4 - Desember 2012): 506. 
Undang-Undang Nomor 2 Tahun 2011 tentang Perubahan Atas Undang-Undang Nomor 2 Tahun 2008 tentang Partai Politik, adalah penyempurnaan regulasi atas Undang-undang Nomor 2 tahun 2008 tentang Partai Politik yang diundangkan pada Januari 2008 dan menjadi salah satu pedoman dalam penyelenggaraan Pemilu tahun 2009. Bila melihat lembar penjelasan umum yang ada pada undangundang ini, dapat ditemukan bahwa UU ini mencita-citakan terbangunnya Penataan dan penyempurnaan Partai Politik sebagai pilar demokrasi untuk mewujudkan sistem politik yang demokratis dan mampu mendukung terbangunnya sistem presidensiil yang efektif. Usaha penataan tersebut diarahkan pada dua hal utama, yaitu, Pertama, membentuk sikap dan perilaku Partai Politik yang terpola atau sistemik sehingga terbentuk budaya politik yang mendukung prinsip-prinsip dasar sistem demokrasi. Hal ini ditunjukan dengan sikap dan perilaku Partai Politikyangmemiliki sistem seleksi dan rekrutmen keanggotaan yang memadai serta mengembangkan sistem pengkaderan dan kepemimpinan politik yang kuat. Kedua, memaksimalkan fungsi Partai Politik baik fungsi Partai Politik terhadap negara maupun fungsi Partai Politik terhadap rakyat melalui pendidikan politik dan pengkaderan serta rekrutmen politik yang efektif untuk menghasilkan kader-kader calon pemimpin yang memiliki kemampuan di bidang politik.

Khususnya terkait usaha penguatan kelembagaan partai, baik Undang-Undang Pemilu maupun Undang-Undang Partai Politik mensyaratkan bahwa partai politik peserta pemilu harus berstatus badan hukum, memiliki kepengurusan di seluruh provinsi, memiliki kepengurusan di $75 \%$ (tujuh puluh lima persen) jumlah kabupaten/kota di provinsi yang bersangkutan, memiliki kepengurusan di 50\% (lima puluh persen) jumlah kecamatan di kabupaten/kota yang bersangkutan, menyertakan sekurang-kurangnya 30\% (tiga puluh persen) keterwakilan perempuan pada kepengurusan partai politik tingkat pusat. Selain itu, di dalam Undang-Undang Pemilu tahun 2012 persyaratan bagi partai peserta pemilu juga adalah memiliki anggota sekurangkurangnya 1.000 (seribu) orang atau $1 / 1.000$ (satu perseribu) dari jumlah penduduk pada kepengurusan partai politik yang dibuktikan dengan kepemilikan kartu tanda anggota, dan mempunyai kantor tetap untuk kepengurusan pada tingkatan pusat, provinsi, dan kabupaten/ kota sampai tahapan terakhir Pemilu.

Pada sisi lain, upaya memelihara dan mengefektifkan berjalannya sistem presidensiil yang digunakan oleh Indonesia, dilakukan pada empat hal yaitu; Pertama, mengkondisikan terbentuknya sistem multipartai sederhana; Kedua, mendorong terciptanya pelembagaan partai yang demokratis dan akuntabel; Ketiga, mengkondisikan terbentuknya kepemimpinan partai yang demokratis dan akuntabel; dan keempat mendorong penguatan basis dan struktur kepartaian pada tingkat masyarakat. Pencapaian seluruh kondisi tersebut, diusahakan melalui dilakukannya pengaturan dalam undangundang ini terkait persyaratan pembentukan partai politik, persyaratan kepengurusan partai politik, perubahan AD dan ART, rekrutmen dan pendidikan politik, pengelolaan keuangan partai politik dan kemandirian partai politik. ${ }^{26}$

26 Lihat Penjelasan Undang-Undang Republik Indonesia Nomor 2 Tahun 2011 tentang Perubahan Atas UndangUndang Nomor 2 Tahun 2008 Tentang Partai Politik. 


\section{$\mathrm{R}_{\text {juknaL }}^{\text {juTSVINDING }}$}

Demikian pula dari sisi penyelenggaraan pemilu, Undang-Undang Nomor 8 Tahun 2012 tentang Pemilu telah memberikan regulasi terhadap partai politik yang ingin turut serta dalam pemilu, persyaratan disusun sedemikian rupa sehingga proses demokratisasi dapat terus berlanjut dengan baik melalui penyelenggaraan pemilu yang lebih berkualitas, terkelola dan terlembaga. Melalui pemilu yang berkualitas diharapkan tercipta derajat kompetisi yang sehat, partisipatif, dan mempunyai derajat keterwakilan yang lebih tinggi, serta memiliki mekanisme pertanggungjawaban yang jelas. Beberapa hal yang diatur dalam UndangUndang Pemilu adalah yang berkaitan dengan penyempurnaan tahapan penyelenggaraan pemilu, persyaratan partai politik menjadi peserta pemilu, pendaftaran partai politik menjadi peserta pemilu, batas waktu verifikasi partai politik calon peserta pemilu, mekanisme penggunaan hak memilih Warga Negara Indonesia, sistem informasi data pemilih, penyusunan daftar pemilih, kampanye pemilu, pemungutan suara, kriteria penyusunan daerah pemilihan, penentuan ambang batas, sistem pemilu proporsional, penetapan calon terpilih, dan penanganan laporan pelanggaran pemilu, serta pelanggaran kode etik penyelenggara pemilu, pelanggaran administrasi pemilu, sengketa pemilu, tindak pidana pemilu, sengketa tata usaha negara pemilu, dan perselisihan hasil pemilu.

Dengan cita-cita yang demikian ideal, atas kondisi lembaga kepartaian yang akan mengikuti pemilu dan menempatkan kaderkader andalannya sebagai wakil dan pemimpin seluruh rakyat Indonesia ke depan, tentu membutuhkan ketersediaan waktu yang cukup untuk mewujudkannya. Terlebih mengingat perkembangan kondisi dan dinamika partai politik di Indonesia saat ini, yang masih sering mendapat penilaian yang mengecewakan dari mastyarakat.

Meskipun demikian, banyak dari pihak partai politikyangkemudian mengkritisiisidariUndangUndang Partai Politik maupun Undang-Undang pemilu. Perihal yang paling banyak dikritisi oleh partai-partai diantaranya mengenai peningkatan ambang batas yang tinggi dalam Pemilu 2014. Setiap partai sepakat bahwa penerapan ambang batas memang dimaksudkan sebagai upaya untuk menyederhanakan sistem kepartaian, tetapi di lain pihak, peningkatan ambang batas yang tinggi dan kurang wajar itu juga akan menambah jumlah suara terbuang. Padahal penambahan jumlah suara terbuang berakibat pada meningkatnya disproporsionalitas hasil pemilu dan hal ini yang seharusnya dihindari dalam sistem pemilu proporsional.

Untuk memperkuat, partai-partai yang menggugat pasal mengenai ambang batas dalam Undang-Undang Pemilu, memberikan contoh dengan mengemukakan data KPU yang menggambarkan bahwa pada Pemilu 1999 yang tidak menerapkan ambang batas, terdapat 3.755.383 (3,55\%) suara terbuang. Jika ambang batas diterapkan, jumlah suara terbuang akan bertambah. Misalnya dengan besaran ambang batas 2,5\%, yang diterapkan pada Pemilu 2009, maka jumlah suara terbuang melonjak lima kali lipat menjadi 14.195.221(13,41\%). Hal ini berarti ambang batas mempunyai pengaruh positif terhadap peningkatan disproporsionalitas hasil pemilu.

Semestinya setiap kriteria yang dimintakan terhadap partai politik untuk menjadi peserta pemilu tidak ditempatkan sebagai beban berat irasional yang harus dipenuhi partai hanya dalam jangka waktu satu atau dua tahun menjelang penyelenggaraan pemilu. Kriteria 
yang tertera dalam undang-undang, adalah target pelembagaan organisasi kepartaian yang harus dibangun secara gradual dan tidak instan hingga partai memiliki eksistensi yang nyata ditengah masyarakat.

Namun perkembangan yang terlihat, problematika kepartaian Indonesia saat ini tidak lagi terkait dengan faktor sistem yang mendasarinya karena sistem dan regulasi yang digunakan saat ini sesungguhnya telah relatif demokratis. Problematika kepartaian Indonesia sekarang ternyata lebih terletak pada faktor internal partai politik. Berbagai problema tengah mendera kepartaian di Indonesia saat ini. Partai politik di Era Reformasi ternyata cenderung lebih berkutat pada cita-cita primitifnya, yaitu sekadar meraih dan mempertahankan kekuasaan, dengan mengerahkan segala daya upaya demi mewujudkan pragmatisme politiknya. Lebih parah lagi bila pragmatisme politik ini bertemu dengan pragmatisme ekonomi, maka politik kepartaian yang ada akan menjadi transaksional dan sibuk memburu rente (rent-seekers). ${ }^{27}$

\section{Politik Hukum yang Dipilih untuk Mendorong Penguatan Kelembagaan Partai}

Hampir setiap literatur menyebutkan bahwa sistem politik demokratis adalah prasyarat wajib yang harus ada untuk dapat memfasilitasi kehidupan partai politik yang bebas, otonom, dan kompetitif, atau dengan kata lain untuk menciptakan demokratisasi partai politik mensyaratkan terlebih dahulu dilakukannya demokratisasi sistem politik. Dalam sistem politik non-demokratis, kehidupan partai politik umumnya tidak bebas, tidak otonom, dan tidak kompetitif. Namun kalaupun sistem politik yang ada telah relatif demokratis, dalam berjalannya suatu demokrasi perwakilan tidak hanya mensyaratkan keberadaan partai politik, tetapi juga menuntut agar partai politik memberi kontribusi positif dan konstruktif terhadap terwujudnya praktik demokrasi perwakilan berkualitas, artinya sepak-terjang partai politik merupakanvariabelyangmempengaruhikualitas demokrasi. Jika partai politik menjalankan peran dan fungsinya dengan baik, kualitas demokrasi akan menjadi baik, begitu pula sebaliknya. Dalam sistem demokrasi perwakilan, kondisi partai politik merupakan barometer atas kualitas praktik demokrasi secara umum.

Dalam konteks Indonesia pasca amandemen UUD 1945, partai politik berperan penting bukan hanya dalam aspek kontestasi elektoral, tetapi juga dalam aspek ketatanegaraan. Dalam aspek elektoral, partai politik merupakan kendaraan politik untuk ikut dalam perebutan jabatan publik eksekutif di pusat dan daerah. Sementara dalam aspek ketatanegaraan, partai politik yang memiliki kepanjangan tangan di lembaga DPR dapat terlibat dalam pembuatan keputusan yang bukan hanya berhubungan dengan domain utama legislatif (legislasi, pengawasan, dan anggaran), tetapi juga berwenang dalam memutuskan dan menentukan banyak hal. Singkatnya, Era Reformasi adalah era surplus kekuasaan partai politik (partytocracy). ${ }^{28}$

Merujuk pada Pasal 71 Undang-Undang Nomor 27 Tahun 2009 tentang Majelis Permusyawaratan Rakyat, Dewan Perwakilan Rakyat, Dewan Perwakilan Daerah, dan Dewan Perwakilan Rakyat Daerah, menyebutkan bahwa

Munafrizal Manan, Op.Cit., hlm. 513-514.

28 Munafrizal Manan, Op.Cit. hlm. 512. 


\section{RECHTSVINDING

hal-hal yang menjadi tugas dan wewenang DPR adalah:

a. Membentuk undang-undang yang dibahas dengan Presiden untuk mendapat persetujuan bersama.

b. Memberikan persetujuan atau tidak memberikan persetujuan terhadap peraturan pemerintah pengganti undangundang yang diajukan oleh Presiden untuk menjadi undang-undang.

c. Menerima rancangan undang-undang yang diajukan oleh DPD berkaitan dengan otonomi daerah, hubungan pusat dan daerah, pembentukan dan pemekaran serta penggabungan daerah, pengelolaan sumber daya alam dan sumber daya ekonomi lainnya, serta yang berkaitan dengan perimbangan keuangan pusat dan daerah.

d. Membahas rancangan undang-undang bersama Presiden dan DPD sebelum diambil persetujuan bersama antara DPR dan Presiden.

e. Membahas rancangan undang-undang yang diajukan oleh Presiden atau DPR yang berkaitan dengan otonomi daerah, hubungan pusat dan daerah, pembentukan dan pemekaran serta penggabungan daerah, pengelolaan sumber daya alam dan sumber daya ekonomi lainnya, serta perimbangan keuangan pusat dan daerah, dengan mengikutsertakan DPD sebelum diambil persetujuan bersama antara DPR dan Presiden.

f. Memperhatikan pertimbangan DPD atas rancangan undang-undang tentang APBN dan rancangan undang-undang yang berkaitan dengan pajak, pendidikan, dan agama;

g. Membahas bersama Presiden dengan memperhatikan pertimbangan DPD dan memberikan persetujuan atas rancangan undang-undang tentang APBN yang diajukan oleh Presiden.

h. Melakukan pengawasan terhadap pelaksanaan undang-undang dan APBN.

i. Membahas dan menindaklanjuti hasil pengawasan yang disampaikan oleh DPD terhadap pelaksanaan undang-undang mengenai otonomi daerah, pembentukan, pemekaran, dan penggabungan daerah, hubungan pusat dan daerah, pengelolaan sumber daya alam dan sumber daya ekonomi lainnya, pelaksanaan APBN, pajak, pendidikan, dan agama.

j. Memberikan persetujuan kepada Presiden untuk menyatakan perang, membuat perdamaian dan perjanjian dengan negara lain, serta membuat perjanjian internasional lainnya yang menimbulkan akibat yang luas dan mendasar bagi kehidupan rakyat yang terkait dengan beban keuangan negara dan/atau mengharuskan perubahan atau pembentukan undang-undang.

k. Memberikan pertimbangan kepada Presiden dalam pemberian amnesti dan abolisi.

I. Memberikan pertimbangan kepada Presiden dalam hal mengangkat duta besar dan menerima penempatan duta besar negara lain.

m. MemilihanggotaBPKdenganmemperhatikan pertimbangan DPD

n. Membahas dan menindaklanjuti hasil pemeriksaan atas pengelolaan dan tanggung jawab keuangan negara yang disampaikan oleh BPK.

o. Memberikan persetujuan kepada Presiden atau pengangkatan dan pemberhentian anggota Komisi Yudisial.

p. Memberikan persetujuan calon hakim agung yang diusulkan Komisi Yudisial untuk 
ditetapkan sebagai hakim agung oleh Presiden.

q. Memilih 3 (tiga) orang hakim konstitusi dan mengajukannya kepada Presiden untuk diresmikan dengan keputusan Presiden.

r. Memberikan persetujuan terhadap pemindahtanganan aset negara yang menjadi kewenangannya berdasarkan ketentuan peraturan perundang-undangan dan terhadap perjanjian yang berakibat luas dan mendasar bagi kehidupan rakyat yang terkait dengan beban keuangan negara.

s. Menyerap, menghimpun, menampung, dan menindaklanjuti aspirasi masyarakat.

t. Melaksanakan tugas dan wewenang lain yang diaturdalam undang-undang.

Lebih dari itu dalam melakukan investigasi untuk menghimpun dan menindak lanjuti permasalahan yang terjadi terkait segala aspek permasalahan dalam kehidupan bernegara, DPR memiliki hak untuk meminta pejabat negara, pejabat pemerintah, badan hukum, atau warga masyarakat untuk memberikan keterangan tentang suatu hal yang perlu ditangani demi kepentingan bangsa dan negara, dan setap pihak yang dipanggil oleh DPR untuk dimintai keterangan berkewajiban untuk memenuhi permintaan DPR tersebut. Bahkan, setiap pejabat negara, pejabat pemerintah, badan hukum, atau warga masyarakat yang tidak memenuhi panggilan DPR dapat dikenakan panggilan paksa, dan bila panggilan paksa tersebut juga tidak dipenuhi maka DPR dapat melakukan penyanderaan terhadap pihak yang bersangkutan paling lama 15 (lima belas) hari sesuai dengan ketentuan peraturan perundangundangan. ${ }^{29}$
Tidak dapat dipungkiri, bahwa kewenangan dan hak yang saat ini dimiliki DPR merupakan implementasi atas aspirasi keinginan untuk memperkuat fungsi dan kedudukan DPR dalam sistem bernegara di Indonesia, mengingat pada era Orde Lama dan era Orde Baru fungsi dan kedudukan DPR masih sangat lemah. Penguatan fungsi damn kedudukan DPR didalam amandemen UUD 1945 tidak lain adalah untuk membangun keseimbangan serta check and balances antar lembaga negara dimana dalam beberapa periode pemerintahan sebelumnya belum terwujud.

Politik hukum yang terkandung di dalam Undang-Undang Nomor 27 Tahun 2009 tentang MPR, DPR, DPD dan DPRD ini, selayaknya selaras dengan segala maksud yang melatarbelakangi ditetapkannya segala regulasi menyangkut kelembagaan partai. Sebagai negara yang berkedaulatan rakyat yang dalam pelaksanaannya menganut prinsip kerakyatan yang dipimpin oleh hikmat kebijaksanaan dalam permusyawaratan/ perwakilan, keberadaan lembaga perwakilan rakyat yang mampu mengejewantahkan nilai-nilai demokrasi serta dapat menyerap dan memperjuangkan aspirasi rakyat di seluruh wilayah Indonesia, agar sesuai dengan tuntutan perkembangan kehidupan berbangsa dan bernegara sudahmerupakan keniscayaan.

Partai politik sebagai unsur utama yang mengisi lembaga perwakilan rakyat melalui penetapan berbagai regulasi diharuskan memenuhi standar kapasitas sebagai sarana partisipasi politik masyarakat dalam upaya mewujudkan cita-cita nasional bangsa Indonesia, dan mengembangkan kehidupan

29 Lihat Pasal 72 Undang-Undang Nomor 27 Tahun 2009 Tentang Majelis Permusyawaratan Rakyat, Dewan Perwakilan Rakyat, Dewan Perwakilan Daerah, Dan Dewan Perwakilan Rakyat Daerah. 


\section{$\mathrm{R}_{\text {juknaL }}^{\text {juTSVINDING }}$

demokrasi berdasarkan Pancasila. Secara mikro kapasitas yang diharapkan dari partai politik adalah dimilikinya kemampuan sebagai sarana partisipasi politik warga negara Indonesia yang berdedikasi, sebagai sarana pendidikan politik bagimasyarakat mengenai hak dan kewajibannya dalam kehidupan bermasyarakat, berbangsa, dan bernegara, partai politik juga diharapkan mampu menyerap, dan menyalurkan aspirasi politik masyarakat secaara jujur dan konsisten dalam rangka merumuskan dan menetapkan kebijakan negara, dan menjadi sarana rekrutmen politik yang objektif dalam proses pengisian jabatan politik melalui mekanisme demokrasi.

\section{E. Penutup}

Negara ini telah menetapkan diri untuk menggunakan sistem demokrasi dalam menjalankan kehidupan politik bernegaranya. Sistem demokrasi yang dianut diaplikasikan melalui prinsip kedaulatan rakyat yang dipimpin oleh hikmat kebijaksanaan dalam permusyawaratan/perwakilan.

Sistem demokrasi perwakilan ini yang kemudian memberikan konsekuensi kepada partai politik untuk berperan menjadi pilar demokrasi dalam kehidupan bernegara di Indonesia.

Dengan segala kewenangan dan hak yang dimilliki serta fungsi yang harus dipenuhi oleh partai politik dimana telah diatur dalam undang-undang, kelembagaan partai politik di Indonesia saat ini terlihat masih memiliki banyak kendala dan belum memenuhi kapasitas untuk menjalankan perannya sesuai dengan yang diharapkan. Permasalahan paling menonjol yang dialami oleh partai politik saat ini dapat dilihat dari maraknya kasus pelanggaran hukum yang saat ini terjadi diantara para kader partai, khususnya yang telah duduk sebagai anggota DPR maupun sebagai pejabat negara lainnya, kondisi ini juga berdampak pada terus menurunnya tingkat kepercayaan masyarakat terhadap partai politik. Beberapa sumber kendala yang kemudian dapat diidentifikasi diantaranya adalah:

- kebutuhan partai politik akan dana besar untuk memenangkan pemilu telah membebani para politisi yang merupakan kadernya untuk berlaku koruptif;

- saat ini partai masih terlihat belum mampu melakukan fungsi perekrutan politik secara demokratis, transparan, dan berbasis meritokrasi;

- kegagalan partai dalam membangun sistem kaderisasi,ideologisasi dan fungsi pendidikan politik berdampak munculnya pragmatisme dalam kelembagaan partai;

- Pragmatisme yang marak dalam kehidupan kepartaian telah mengeliminir rasa militansi kader, dalam kondisi dilematis tersebut partai akan terdorong untuk menggunakan cara instan menarik simpati pemilih dan melakukan politik uang.

Undang-undang Nomor 2 Tahun 2008 tentang Partai Politik yang berlaku saat ini mensyaratkan berbagai hal terkait kelengkapan organisasi partai politik, mulai dari pembentukan dan pendirian partai politik, kepengurusan, dan status hukum. Beberapa hal yang harus dipenuhi oleh partai terkait tujuan, fungsi, hak dan kewajiban dari partai politik, juga diatur dalam undang-undang.

Terkait peran serta partai dalam pemilihan umum, juga diatur mulai dari kepemilikan kantor tetap, jumlah minimum dari anggota partai, jumlah minimum keanggotaan perempuan, jumlah minimum dukungan, hingga memenuhi jumlah kepengurusan tertentu di wilayah kabupaten/kota dan provinsi. Semakin ketatnya persyaratan dalam pembentukan 
dan keikutsertaan partai dalam pemilu diumaksudkan untuk melakukan penguatan lembaga kepartaian melalui pembentukan sistem multi partai sederhana. Dengan dinamika politik yang lebih stabil dan domkratisasi yang tetap terpelihara diharapkan akan memperkuat sistem presidensiil yang berjalan.

Kuatnya kelembagaan partai politik yang ada akan berpengaruh secara signifikan terhadap kualitas sistem demokrasi yang berjalan. Terlebih dalam konteks Indonesia dimana partai politik telah diberikan kewenangan dalam menentukan banyak hal selain dari domain legislasi, bahkan banyak dari kewenangan yang dimiliki oleh presiden yang terlebih dahulu harus dikonsultasikan bersama DPR. Ketatnya pengaturan terkait pendirian dan keikutsertaan partai dalam pemilu, selayaknya tidak dilihat sebagai usaha penyempitan saluran aspirasi rakyat, namun dilihat sebagai usaha pembentukan kelembagaan partai dan kelembagaan perwakilan rakyat yang kuat dan ideal.

\section{DAFTAR PUSTAKA}

\section{Buku}

Gaffar, Afan, Politik Indonesia Menuju Transisi Menuju Demokrasi, (Yogyakarta: Pustaka Pelajar, 1999).

Hikam, Muhammad AS., Politik Kewarganegaraan, Landasan Redemokratisasi di Indonesia (Jakarta: PT. Gelora Aksara Perdana, 1999).

Huntington, Samuel P., The Third Wave Democratization in the Late Twentieth Century, (Oklahoma: University of Oklahoma Press, Norman, 1991).

Kemitraan, Anomali Keuangan Partai Politik Pengaturan Dan Praktek, (Jakarta: Kemitraan, 2011).

Koalisi Perempuan Indonesia, Refleksi 2012 \& Catatan Awal Tahun 2013, Kegaduhan Politik \& Maraknya Korupsi Di Tengah Kemiskinan
Akut \& Kekerasan (Jakarta: Koalisi Perempuan Indonesia, 2013).

Robert Michels, The Iron Law of Oligarchy, dalam Bernard E. Brown dan Roy C. Macridis, Comparative Politics: Notes and Readings, 8th Edition, (California: Wadsworth Publishing Company, 1996).

Muchlis M, Edison, Perbandingan Pelembagaan Lima Partai Politik, dalam Sri Nuryanti (ed.) Pelembagaan Partai Politik di Indonesia Pasca Orde Baru, (Jakarta: LIPI, Pusat Penelitia Politik, 2007).

Schumpeter, Joseph A., Capitalism, Socialism and Democracy, (London: Unwin Paperbacks, 1987).

Surbakti, Ramlan dan Didik Supriyanto, Menjaga Kedaulatan Pemilih, Buku Seri Demokrasi Elektoral, (Jakarta: Kemitraan, September 2011).

\section{Makalah/Artikel/Prosiding/Hasil Penelitian}

Kompas, "Skor Indonesia Kembali Memburuk", 19 September 2012.

Manan, Munafrizal, "Partai Politik dan Demokrasi Indonesia Menyongsong Pemilihan Umum 2014", Jurnal Legislasi Indonesia (Vol. 9 No. 4 Desember 2012).

Romli, Lili, "Masalah Kelembagaan Partai Politik di Indonesia Pasca Orde Baru," Jurnal Penelitian Politik (Volume 5 No. 1, 2008).

Yuda Ar, Hanta, Sindrom Partai Gagal, Kompas 27 Mei 2011.

\section{Internet}

"Visi dan misi PDI-Perjuangan", www.pdiperjuangan. or.id (diakses 12 November 2012).

ICW, "Laporan Catatan Akhir Tahun ICW Terkait Korupsi Politik 2012", www.lensaindonesia.com (diakses 10 Desember 2012).

\section{Peraturan}

Undang-Undang Nomor 27 Tahun 2009 Tentang Majelis Permusyawaratan Rakyat, Dewan Perwakilan Rakyat, Dewan Perwakilan Daerah, Dan Dewan Perwakilan Rakyat Daerah.

Undang-Undang Republik Indonesia Nomor 2 Tahun 2011 tentang Perubahan Atas Undang-Undang Nomor 2 Tahun 2008 Tentang Partai Politik.

Undang-Undang Nomor 8 tahun 2012 tentang Pemilihan Umum Anggota Dewan Perwakilan 
Rakyat, Dewan perwakilan Daerah, dan Dewan Perwakilan rakyat Daerah.

Anggaran Dasar Partai Demokrat.

Anggaran Dasar Partai Persatuan Pembangunan

(PPP), hasil Muktamar VI tahun 2007. 